\title{
Rafał Siekiera*
}

\section{Stosunki nadawczo-odbiorcze w internetowej relacji sportowej "na żywo"}

Internetowa relacja „na żywo”, jako gatunek spokrewniony z telewizyjną transmisją sportową oraz relacją internetową, charakteryzuje się - jak mogłoby się wydawać - zbliżoną do wymienionych form wypowiedzi sytuacją komunikacyjną. Nadawca obserwuje wydarzenie sportowe i na bieżąco przekazuje swoje spostrzeżenia odbiorcom. W telewizji głos komentatora jest jednym z elementów polisemicznego przekazu i stanowi raczej uzupełnienie warstwy ikonicznej, podczas gdy w radiu staje się on jedynym źródłem wiedzy słuchacza o przebiegu zawodów. Medium internetowe daje nadawcy nieco więcej możliwości, nie zmuszając go do wykorzystania jedynie słowa. Sytuacja pozostaje mimo wszystko zbliżona do relacji radiowej - odbiorca z założenia nie widzi opisywanych i interpretowanych zdarzeń.

Wyjściowe założenia nie oddają jednak rzeczywistości. Współcześnie przeprowadzanie tego typu rozgraniczeń jest ryzykowne. Pogłębiająca się od lat konwergencja mediów powoduje stopniowe zbliżanie się do siebie form przekazu charakterystycznych dla różnych nadawców medialnych. W przypadku wymienionych gatunków (w ujęciu genologicznym transmisja telewizyjna może być traktowana jako kolekcja gatunków o budowie modułowej ${ }^{1}$ lub jako jedna z odmian widowiska telewizyjnego ${ }^{2}$ ) podobieństwo dotyczy niektórych elementów składowych (np. możliwości wykorzystania materiałów wideo w relacji internetowej lub inter-

* Dr, Uniwersytet Łódzki, Wydział Filologiczny, Katedra Dziennikarstwa i Komunikacji Społecznej, e-mail: rafal.siekiera@uni.lodz.pl.

1 Por. B. Grochala, Telewizyjna transmisja sportowa w ujęciu genologii lingwistycznej. Na materiale transmisji meczów piłki nożnej, Wydawnictwo UŁ, Łódź 2016, s. 49.

2 Zdaniem Stanisława Kuszewskiego widowiskiem telewizyjnym może być każda umieszczona w programie telewizyjnym całościowa struktura posiadająca wyraźnie zarysowane ramy 
aktywności przekazu radiowego i telewizyjnego dzięki mediom społecznościowym). Co więcej, odbiorca nie musi być skrępowany ograniczeniami jednego medium - może wszak śledzić przebieg zawodów w telewizji i jednocześnie w komputerze odczytywać kolejne wpisy relacji internetowej (tym bardziej wówczas, gdy oferuje ona możliwość komentowania spostrzeżeń nadawcy). Symultaniczność obecności wydarzenia sportowego w różnych środkach przekazu jest dziś standardem, a nie wyjątkiem. Sami dziennikarze sportowi przyznają, że nawet będąc na stadionie, coraz rzadziej spoglądają na boisko/parkiet/tor, a w większym stopniu skupiają uwagę na ekranach swoich smartfonów, laptopów czy tabletów ${ }^{3}$.

Utekstowienie współczesnych wydarzeń sportowych w coraz większym stopniu cechuje współuczestnictwo nadawców i odbiorców (choć relacjonowanie zawodów przez tych pierwszych wciąż pozostaje cechą nadrzędną). Z punktu widzenia lingwistyki tekstu interesującym zagadnieniem jest wpływ polimedialności widowisk sportowych na relacje nadawczo-odbiorcze w wymienionych gatunkach. Niniejsze opracowanie stawia sobie za cel dokonanie charakterystyki sytuacji nadawczo-odbiorczej w internetowych relacjach "na żywo”.

Materiał badawczy obejmował 150 losowo wybranych relacji z lat 2012-2017, opisujących zawody różnych dyscyplin, m.in.: piłki nożnej, piłki ręcznej, siatkówki, koszykówki, tenisa ziemnego, hokeja na lodzie, Formuły 1, biegów narciarskich, futsalu ${ }^{4}$, skoków narciarskich ${ }^{5}$. Różnorodność dyscyplin pozwala na dokonanie możliwie szerokiego oglądu relacji nadawczo-odbiorczych i uniknięcie zawężenia

czasowe (por. S. Kuszewski, Widowisko telewizyjne, Wydawnictwa Artystyczne i Filmowe, Warszawa 1971, s. 44).

3 Por.: „W mediach społecznościowych, gdzie jest zjawisko second-screeningu, kiedy ludzie nie są w stanie oglądać sportu, nawet na trybunach, bez Twittera w ręku [...], tworzy się chęć współuczestnictwa, współkomentowania, dzielenia się swoimi myślami, chęć przeczytania innych, zobaczenia powtórki, zaśmiania się memem, GIF-em. [...] Nie ma w tym nic dziwnego, że dziennikarze stają się współuczestnikami wydarzenia, które nie dzieje się już wyłącznie na boisku. Ono dzieje się też zupełnie gdzie indziej, jest odbierane i przeżywane w mediach społecznościowych. [...] Zdarzało mi się wielokrotnie chodzić na mecze i tweetować w trakcie, a potem siadać i pisać obiektywną relację" (M. Pol, Dziennikarstwo sportowe 2.o, rozm. przepr. P. Szews, [w:] P. Szews, R. Siekiera, Zawód: dziennikarz/komentator sportowy. Kulisy pracy i warsztatu, Wydawnictwo UŁ, Łódź 2016, s. 188.) oraz: „[...] wracając na chwilę do zagrożeń związanych z mediami społecznościowymi, znam takich dziennikarzy, którzy siedząc na stadionie, patrzą głównie w telefon albo w iPada. Oni już nie patrzą na boisko, bo są zajęci tym tweetowaniem. U mnie zależy to od meczu. Jak się nic nie dzieje, to oglądam w trakcie, jeśli dzieje się dużo, to powstrzymuję się do przerwy. Twitter psuje oglądanie. Dziś już mniej uważnie oglądam mecze niż kiedyś" (R. Stec, Krytyczne spojrzenie na futbolowy mikrokosmos, rozm. przepr. P. Szews, [w:] P. Szews, R. Siekiera, dz. cyt., s. 135).

4 Halowa, 5-osobowa odmiana piłki nożnej.

5 W opisach bibliograficznych cytowanych fragmentów relacji zastosowano następującą formułę: nazwa dyscypliny, wskazanie konkretnego wydarzenia, data zawodów, link do zapisu relacji, data dostępu (w nawiasie kwadratowym). 
perspektywy do cech charakterystycznych dla jednego sportu. Źródłem materiału - z podobnych powodów - były zróżnicowane strony internetowe (m.in. interia.pl, onet.pl, realmadryt.pl, lajfy.com, zczuba.pl, live.niebiescy.pl, relacjelive.net). Ograniczenie do jednej bądź dwóch witryn mogłoby spowodować zafałszowanie wyników, gdyż relacja internetowa nie jest jeszcze gatunkiem w pełni ukonstytuowanym, a jednostkowe realizacje mogą posiadać cechy charakterystyczne dla macierzystej witryny (np. nieformalność przekazu zczuba.pl czy większa zachowawczość relacji w serwisie interia.pl bądź relacjelive.net).

O relacjach internetowych pisano jak dotąd niewiele. Do autorów poruszających tę tematykę należą Beata Grochala ${ }^{6}$, Katarzyna Burska ${ }^{7}$, Przemysław Szews ${ }^{8}$, a za granicą - Jan Chovanec'. Przywołani autorzy skupiają się jednak w większym stopniu na aspektach językowych lub genologicznych. Na element interpersonalny gatunku zwrócił uwagę Chovanec, pisząc:

analizowane relacje są złożonymi zdarzeniami językowymi, w których słowna relacja autora uzupełniona jest przez przytoczone słowne komentarze innych sprawozdawców oraz cytaty z osobistych wypowiedzi poszczególnych czytelników, nadesłanych do komentatora drogą mailową. [...] W rezultacie relacja staje się wysoce spersonalizowaną formą autoekspresji komentatora, odbiegającą znacznie od zwykłego opisu wydarzeń mających miejsce podczas meczu piłkarskiego ${ }^{10}$.

6 B. Grochala, Internetowy komentarz sportowy na żywo jako nowa (?) formuła komentarza sportowego, [w:] Język żyje. Rzecz o współczesnej polszczyźnie, red. K. Ożóg, Wydawnictwo Uniwersytetu Rzeszowskiego, Rzeszów 2009, s. 209-217; B. Grochala, Ten sam gatunek w dwóch odmianach - o telewizyjnej i internetowej relacji sportowej na żywo, [w:] Gatunki mowy i ich ewolucja, t. 4: Gatunek a komunikacja społeczna, red. D. Ostaszewska, Wydawnictwo UŚ, Katowice 2011, s. 169-180; B. Grochala, Język internetowej relacji sportowej na żywo, [w:] Język nowych mediów, red. K. Michalewski, Primum Verbum, Łódź 2012, s. 21-30; B. Grochala, Kompetencja komunikacyjna a gatunek. O internetowej relacji na żywo, „Acta Universitatis Lodziensis. Kształcenie Polonistyczne Cudzoziemców" 2013, nr 2(20), s. 306-307.

7 K. Burska, Z Czuba i na żywo - językowe sposoby kształtowania relacji sportowych na żywo na portalu internetowym www.zczuba.pl, [w:] Sport w mediach, red. M. Jarosz, P. Drzewiecki, P. Płatek, Dom Wydawniczy Elipsa, Warszawa 2013, s. 46-72.

8 P. Szews, Internetowa relacja „live”, [w:] P. Szews, R. Siekiera, dz. cyt., s. 69-84.

9 J. Chovanec, Enacting an imaginary community: infotainment in online minute-by-minute sports commentaries, [w:] The Linguistics of football, red. E. Lavric, G. Pisek, A. Skinner, W. Stadler, Gunter Narr Verlag, Tübingen 2008, s. 255-268.

10 "The commentaries analysed are complex speech events in which a verbal commentary by the author is complemented with reported verbal commentaries by (and between) other commentators, as well as quotes from personal communications of individual readers sent by email to the commentator. [...] As a result, the commentary becomes a highly personalized form of self-expression by the commentator, far removed from merely describing the events in the football game" (tamże, s. 255; tłum. R.S.). 
Czeski badacz w swej pracy podkreśla wspólną zależność warstwy ideacyjnej i pragmatycznej relacji sportowej. Ta pierwsza, zdaniem Chovanca, współcześnie traci na znaczeniu i w coraz większym stopniu usuwana jest na dalszy plan. Dominantą funkcjonalną staje się interakcja między nadawcą a zarówno wyobrażonym, idealnym odbiorcą, jak i realnymi czytelnikami (w przypadku witryn umożliwiających komentowanie na bieżąco relacji przez społeczność).

Biorąc pod uwagę powyższe, słuszne spostrzeżenia, $\mathrm{w}$ analizie materiału badawczego zwrócono uwagę na istotne elementy odzwierciedlające relacje nadawczo-odbiorcze i wpływające na ich kształtowanie. Są to przede wszystkim formy osobowe czasowników i zaimków, składniki spełniające funkcję fatyczną, formuły inicjalne i finalne tekstów oraz interaktywność.

\section{Formy osobowe czasowników i zaimków}

W relacjach internetowych „na żywo”, jak pisze Szews", można wyróżnić dwa zasadnicze sposoby językowego ukształtowania tekstu - bezosobowe i czysto faktograficzne, opierające się na stylu depeszowym, oraz żywe, dynamiczne, obrazowe, zbliżone do osobistego bloga.

Wiąże się to $\mathrm{z}$ formami osobowymi czasowników, występującymi w badanym materiale. Relacje wykorzystujące model faktograficzny posługują się trzecią osobą liczby pojedynczej lub mnogiej bądź w ogóle unikają form osobowych ${ }^{12}$, opisując przebieg wydarzeń bez żadnego komentarza. Autor w takich wypowiedziach jest całkowicie niewidoczny, jak w poniższym fragmencie:

74 ' Niecelny strzał gospodarzy

74' Rzut rożny dla gospodarzy

72 ' Celny strzał gospodarzy

67 ' Niecelny strzał gospodarzy

$67^{\prime}$ Niebezpieczny rzut wolny dla gospodarzy

$65^{\prime}$ Niecelny strzał gości

64' Celny strzał gości

64' Zmiana w drużynie gospodarzy. Schodzi 6. Adriana Ślęczek, wchodzi 5. Weroni-

ka Morawczyńska ${ }^{13}$.

11 P. Szews, dz. cyt., s. 77.

12 Warto zauważyć, że zdaniem Émile’a Benveniste'a „trzecia osoba nie jest «osobą»; to taka forma czasownika, która wyraża czynność za pomocą «nie-osoby»" (E. Benveniste, Problèmes de linguistique générale, za: A. Wilkoń, Funkcje kategorii gramatycznych w tekstach literackich, Cz. 1: Kategoria osoby, red., A. Wilkoń, „Język Artystyczny” 1986, t. 4, s. 12).

13 Piłka nożna, mecz KS Rysy Bukowina Tatrzańska-Naprzód Sobolów, autor nieznany, 15.11.2015, http://relacjelive.net/relacja_na_zywo/ks_rysy_bukowina_tatrzanska-vs-naprzod_sobolow/1100 [dostęp: 9.03.2017]. 
Kolejne wpisy odpowiadające następującym po sobie minutom meczu cechuje beznamiętność (nawet sformułowanie „niebezpieczny strzał” nie sprawia w tym kontekście wrażenia rzeczywistej oceny) prowadząca do zaniku jakiejkolwiek więzi z odbiorcą. Sam tekst wygląda, jakby powstawał w oparciu o gotowy szablon. Dominantą w przypadku tego typu relacji staje się warstwa ideacyjna. Czytelnik otrzymuje zaledwie niezbędne minimum informacji o przebiegu meczu. Taki sposób relacjonowania zdarzeń nie zachęca odbiorców do dzielenia się z nadawcą własnymi spostrzeżeniami, choć trzeba przyznać, że większość stron opierających się na tym modelu przekazywania informacji „na żywo" nie daje nawet możliwości zostawiania wpisów.

Dużo rzadziej wykorzystuje się trzecią osobę w odniesieniu do samego nadawcy. Pojawia się ona w takiej funkcji jedynie w formułach powitalnych (autor przedstawia się odbiorcom) bądź pożegnalnych:

Koniec meczu.

"Akademiczki” otrzymują srogie baty od zawodniczek z SuperLigi przegrywając, to spotkanie 23-40. Lepsza druga połowa wykonaniu AZS-u. W dniu dzisiejszym świetny procent obronionych rzutów mają zapewne obydwie bramkarki „Góralek”. Za śledzenie relacji serdecznie dziękuje Jarosław Jurkiewicz ${ }^{[4]}$ zapraszając jednocześnie na resztę wieczornych wydarzeń transmitowanych przez portal lajfy. $\mathrm{com}^{15}$.

Wśród form osobowych często występujących w relacjach sportowych „na żywo” najbardziej rozpowszechniona jest pierwsza osoba liczby mnogiej. Jak wskazuje Aleksander Wilkon' ${ }^{16}$, są to formy wieloznaczne, zrelatywizowane do roli nadawcy oraz celu tekstu. W wypowiedziach zakodowanych w tej osobie można wyróżnić zróżnicowane formacje podmiotów biorących udział w akcie komunikacji (lub nazywanych przez nadawcę, choć nieuczestniczących w akcie bezpośrednio).

Należą do nich formy tzw. „MY” ekskluzywnego, obejmującego nadawcę i grupę osób, do których się on zalicza. Jak pisze Janusz Lalewicz, jest to „zbiorowość złożona $\mathrm{Z}$ «pierwszej osoby» (JA) i «osób trzecich» (ONI), określonych przez odniesienie do tej osoby - jako «ci, do których JA należę»" ${ }^{\text {17 }}$ " "MY” rozumiane w taki sposób w przypad-

14 Wszystkie podkreślenia w cytowanych fragmentach relacji pochodzą od autora, zachowano oryginalną ortografię i interpunkcję.

15 Piłka ręczna, mecz AZS AWF Warszawa-MKS Olimpia-Beskid Nowy Sącz, autor: J. Jurkiewicz, 3.02.2016, http://archive.lajfy.com/match/index/date/2016-02-03/id/168959 [dostęp: 4.03.2017].

16 A. Wilkoń, dz. cyt., s. 22.

17 J. Lalewicz, Retoryka kategorii osobowych, [w:] Tekst i zdanie. Zbiór studiów, red. T. Dobrzyńska, E. Janusz, Zakład Narodowy im. Ossolińskich, Wrocław 1983, s. 268. 


\section{Rafał Siekiera}

ku dziennikarzy zazwyczaj oznacza redakcję, którą reprezentuje autor wypowiedzi. Jego prymarną cechą jest perswazyjność. Pozwala ono na powołanie się na autorytet większej grupy osób. Nadawca nie wydaje się osamotniony w swoich sądach, opiniach, spostrzeżeniach czy apelach. „MY” ekskluzywne buduje także jego tożsamość poprzez odniesienie do gruby osób mniej lub bardziej znanej odbiorcy.

Występowanie tej odmiany semantycznej drugiej osoby liczby mnogiej w internetowych relacjach sportowych „na żywo” ma stosunkowo ograniczony zakres. Nie stosuje się jej w celach perswazyjnych, a raczej jako sposób na podkreślenie, że autor relacji reprezentuje redakcję serwisu/portalu (bądź autorami są co najmniej dwie osoby), np.:

Mayday. Mayday. Mamy złe wieści. Stoch skoczył tylko $125 \mathrm{~m}$. W dodatku otrzymał niskie noty, bo miał problemy z lądowaniem. Dopiero dziewiąte miejsce. Szkoda ${ }^{18}$

oraz

3

Cały czas w jednym fragmencie toru mamy żółtą flagę.

4

Żółta flaga już zdjęta. J. Bianchi również poza torem - zapomnieliśmy o tym poinformować ${ }^{19}$.

Innym zastosowaniem „MY” ekskluzywnego w relacjach internetowych jest powitanie lub pożegnanie odbiorców:

Zapraszamy na relację na żywo z pierwszego meczu polskich siatkarzy w tegorocznej edycji Ligi Światowej. „Biało-czerwoni” na wyjeździe zmierzą się z Brazylią ${ }^{20}$.

Końcowy gwizdek sędziego! „Stalówka” przegrywa u siebie z Olimpią Zambrów po golu Roberta Tunkiewicza. Dziękujemy za uwagę! !1 $^{21}$

18 Skoki narciarskie, zawody PŚ w Klingenthal, autorzy: M. Kuprowski, B. Szypowski, 22.11.2015, http://www.zczuba.pl/zczuba/14,123357,19228012,konkurs-indywidualny-w-klingenthal-czyli-zaczynamy-puchar-swiata.html?bo=1 [dostęp: 22.03.2017].

19 Formuła 1, Grand Prix Japonii 2013, 13.10.2013, autor: R. Gnutek, http://archive.lajfy.com/match/index/date/2013-10-13/id/77982 [dostęp: 9.03.2017]. W relacjach z wyścigów Formuły 1 cyferki oddzielające poszczególne wpisy są oznaczeniami okrążeń, podczas których miały miejsce opisywane wydarzenia.

20 Siatkówka, mecz Brazylia-Polska, 29.05.2014, autor: R. Kopeć, http://nazywo.interia.pl/relacja/Is-brazylia-polska,4011 [dostęp: 6.03.2017].

21 Piłka nożna, mecz Stal Stalowa Wola-Olimpia Zambrów, autor nieznany, 24.03.2016, http://relacjelive.net/relacja_na_zywo/stal_stalowa_wola-vs-olimpia_zambrow/1112 [dostęp: 3.03.2017]. 
Najbardziej rozpowszechnioną odmianą semantyczną drugiej osoby liczby mnogiej jest „MY” inkluzywne. Jest ono bliskie takiemu użyciu tej formy osobowej, o którym Wilkoń pisał, że „w języku mówionym używa jej nadawca, jakiś ja, pragnący podkreślić swoją wspólnotę z rozmówcą (rozmówcami) lub nadawcami”22. Spełnia ono zatem funkcję integrującą, buduje poczucie symbolicznej więzi między autorem przekazu a jego odbiorcami. W dziennikarstwie sportowym jest to szczególnie widoczne, kiedy komunikacja towarzyszy występom polskich sportowców. W transmisjach i relacjach z zawodów komentatorzy czują emocjonalną więź z kibicami oraz ze sportowcami. Mogą wówczas odstąpić od zasady bezstronności ${ }^{23}$.

W przeanalizowanych relacjach internetowych „na żywo" poczucie wspólnoty, kiedy startują polscy sportowcy, budowane jest zarówno za pomocą odpowiednich form osobowych czasowników, np.:

Mamy złoto! Piotr Małachowski! I mamy brąz! Robert Urbanek! Jesteśmy najlepsi w rzutach! Juhuuuuu! ${ }^{24}$

Mieliśmy szansę, ale Bułgarzy wykorzystali jednak akcję, 10:8 $8^{25}$.

Massari pomylił się na pojedynczym bloku atakując w aut. Po chwili oddaliśmy łatwo punkt, bo Kurek zepsuł zagrywkę ${ }^{26}$,

jak i zaimków, m.in.:

22 A. Wilkoń, dz. cyt., s. 22.

23 Por. słowa komentatora NC+, Tomasza Smokowskiego: „Twierdzi się, że dziennikarz musi być obiektywny czy bezstronny. W komentowaniu nie zawsze. Oczywiście nie wyobrażam sobie, aby prowadzący transmisję ligowego meczu polskich drużyn komentator mógł sprzyjać którejkolwiek z nich albo żeby robił to jego ekspert. [...]. Ta bezstronność nie obowiązuje jednak - wręcz jest wadą - gdy gra reprezentacja Polski czy polska drużyna klubowa z zagranicznym rywalem. Wtedy komentator musi pokazać, że jest całym sercem za naszą drużyną" (T. Smokowski, Posiedzę z wami dziewięćdziesiąt minut, a potem mnie wyłączycie, [w:] Biblia dziennikarstwa, red. A. Skworz, A. Niziołek, Wydawnictwo Znak, Kraków 2010, s. 183).

24 Lekkoatletyka, Mistrzostwa Świata 2015 - konkurs rzutu dyskiem, autor: K. Sobczak, 29.08.2015, http://www.zczuba.pl/zczuba/14,123357,18651752,wzorzec-relacji-na-zywo-wall-dla-serwisow-nie-kasowac.html?wall=1\&bo=1 [dostęp: 8.03.2017].

25 Siatkówka, mecz Polska-Bułgaria, autorzy: P. Pieprzyca, M. Białoński, 31.07.2012, http://nazywo.interia.pl/relacja/io-polska-bulgaria,3457 [dostęp: 8.03.2017].

26 Siatkówka, mecz Polska-Włochy, autorzy: P. Mikołajczyk, P. Jachym, 16.07.2015, http://www. zczuba.pl/zczuba/14,123357,18378175,polska-wlochy-czyli-final-six-ligi-swiatowej-z-czuba-i-na.html?PageNumber=5 [dostęp: 8.03.2017]. 
40-15

I mamy dwa breakpointy dla naszej zawodniczki! ${ }^{27}$

08:24

Nasi wykorzystują rzuty osobiste - konkretnie Koszarek ${ }^{28}$.

W czwartek nasz zespół rozegrał słabe spotkanie. Dziś liczymy, że zaprezentuje się lepiej, choć celem gospodarzy jest pewne zwycięstwo tak, aby w ostatnim spotkaniu $\mathrm{w}$ niedzielę zagrać ze Słowenią o awans ${ }^{29}$.

W ostatnim cytacie widać także zastosowanie pierwszej osoby liczby mnogiej czasownika 'liczyć'. Trudno rozstrzygnać w tym przypadku, czy jest to „MY” inkluzywne, czy może ekskluzywne (autor może mieć na myśli zarówno siebie i redakcję, jak i siebie wraz z kibicami, a możliwe, że równocześnie siebie, redakcję i kibiców). Wciąż jednak widoczne jest poczucie wspólnoty w obliczu wyzwania, jakie stoi przed polskimi sportowcami.

„MY” inkluzywne stosowane jest także jako narzędzie tworzenia więzi między ludźmi razem przeżywającymi zawody (niekoniecznie - oglądającymi, choć, jak już wspomniano, możliwy jest symultaniczny odbiór relacji internetowej i transmisji telewizyjnej lub radiowej). Odbiorca otrzymuje wówczas substytut wspólnego doświadczania wszystkiego, co składa się na wydarzenie sportowe:

6:30

Stan bramkowy nie ulega zmianie, natomiast mamy pierwsze przewinienie w meczu. Przepisy przekroczyli zawodnicy miejscowego zespołu ${ }^{30}$.

46. min.

Rozpoczynamy drugą połowę spotkania ${ }^{31}$.

27 Tenis ziemny, mecz Magda Linette-Sloane Stephens, autor: P. Grabowski, 5.08.2015, http:// archive.lajfy.com/match/index/date/2015-08-05/id/152155 [dostęp: 24.03.2017].

28 Koszykówka, mecz Polska-Ukraina, autor nieznany, 23.08.2013, http://archive.lajfy.com/match/index/date/2013-08-23/id/74098 [dostęp: 8.03.2017].

29 Hokej, mecz Polska-Białoruś, autor: M. Ząbkiewicz, 2.09.2016, http://nazywo.interia.pl/relacja/kwalifikacje-do-io-bialorus-polska,4528 [dostęp: 6.03.2017].

30 Futsal, mecz FC Toruń-Clearex Chorzów, autor: D. Czempisz, 21.11.2015, http://archive.lajfy. $\mathrm{com} / \mathrm{match} /$ index/date/2015-11-21/id/164785 [dostęp: 8.03.2017].

31 Piłka nożna, mecz Dynamo Kijów-Manchester City, autor: P. Jachym, 24.02.2016, http://www. zczuba.pl/zczuba/14,123357,19674786,dynamo-kijow-manchester-city-czyli-1-8-finalu-ligi-mistrzow.html?PageNumber=1\&PageStep=1 [dostęp: 5.03.2017]. 
09:30

Majewska nie trafiła z dystansu, zbliżamy się do końca pierwszej kwarty ${ }^{32}$.

Wrażenie wspólnego kibicowania ulega wzmocnieniu, kiedy obok form pierwszej osoby liczby mnogiej pojawiają się charakterystyczne dla kibiców bezpośrednie zwroty do rywalizujących sportowców, np.:

$1: 41$

Rosły Kiełpiński wybija piłkę! Sytuacja opanowana. Kocury - czas na atak!

$1: 42$

$\mathrm{Na}$ nic nasze błagania jak na razie - Armand Cela mógł strzelić z najbliższej odległości! $!^{33}$

9:55 Mamy jednak nadzieję, że prawdziwe show dadzą dziś nasi hokeiści. Chłopaki, dajcie ognia! ${ }^{34}$

Autor relacji niejako w imieniu swoim i czytelników dopinguje zawodników. W ten sposób poczucie wspólnoty w sytuacji nadawczo-odbiorczej pogłębia się. Działa to oczywiście jedynie wówczas, gdy prowadzącemu relację znane są sympatie odbiorców. Łatwo o to szczególnie w przypadku serwisów prowadzonych przez miłośników danego klubu i adresowanych do jego fanów.

Dużo rzadziej niż pierwsza osoba liczby mnogiej wykorzystywana jest pierwsza osoba liczby pojedynczej. Nadawca relacji internetowej bezpośrednio ujawnia się zazwyczaj, gdy wprost pisze o swoich spostrzeżeniach:

40 Usłyszałem jakieś gwizdy z trybun. Czy to reakcja na kiepskie zagranie Bale’a? Faktycznie Walijczyk zagrał kiepsko w ostatniej akcji. Zamiast zacentrować w szesnastkę kopnął gdzieś do tyłu³,

bądź w sytuacjach, kiedy wyraża swoje opinie, sądy, oceny dotyczące przebiegu zawodów:

32 Koszykówka, mecz CCC Polkowice-ŽKK Novi Zagreb, autor: P. Szarwark, 20.11.2013, http:// archive.lajfy.com/match/index/date/2013-11-20/id/86177 [dostęp: 8.03.2017].

33 Futsal, mecz KF Tirana-Gatta Active Zduńska Wola, autor: B. Dąbrowski, 18.08.2016, http:// archive.lajfy.com/match/index/date/2016-08-18/id/181457 [dostęp: 8.03.2017].

34 Hokej, mecz Polska-Włochy, autor: M. Ząbkiewicz, 19.04.2015, http://nazywo.interia.pl/relacja/ms-w-krakowie-polska-wlochy,4203 [dostęp: 8.03.2017].

35 Piłka nożna, mecz Real Madryt-Villarreal CF, autorzy: Kielbol/Theo, 1.03.2015, http://www.realmadryt.pl/index.php?co=mecze\&id=1447\&minuta=ok\&akcja=\&id_pilkarz= [dostęp: 9.03.2017]. 
54 Dortmundczycy solidnie przycisnęli po przerwie. Pora na pobudkę Blancos! 55 O tym właśnie pisałem... Kontra Realu środkiem, Oezil prowadzi piłkę, zagrywa prostopadle w swoim stylu, na wolne pole!! Di Maria rusza między dwóch rywali, zbiega na lewo, strzela z kąta!!!!!! MINIMALNIE obok długiego słupka!! Blisko było! Niesamowite są te zrywy Królewskich ${ }^{36}$.

Nadawca w pierwszej osobie liczby pojedynczej występuje także sporadycznie w formułach inicjalnych i finalnych:

Zapraszam na IV etap Tour de Pologne z Tarnowa do Katowic. Odcinek liczący ponad 231 kilometrów jest najdłuższym etapem tegorocznego wyścigu. [...] Dziękuje za uwagę i zapraszam już jutro na kolejny etap Tour de Pologne ${ }^{37}$.

17:55 Witam Państwa w sobotni wieczór, z tej strony TPK i już za nieco ponad godzinę będę relacjonował dla Państwa zapowiadający się niezwykle emocjonująco mecz z Arsenalem na Anfield ${ }^{38}$.

Co prawda w tekstach literackich pierwsza osoba liczby pojedynczej może oznaczać kogoś innego niż autor (twórca wypowiedzi), będąc jedynie maską dla innego podmiotu (rzeczywistego lub wymyślonego), jednak w relacjach internetowych „na żywo” bezpośredniość kontaktu z odbiorcami sprawia, że takie pseudoautorskie „JA" nie ma racji bytu ${ }^{39}$. Badanie zebranego materiału wykazało wyraźną tendencję do budowania więzi między uczestnikami aktu komunikacji ${ }^{40}$.

Pierwsza osoba liczby pojedynczej wpływa na dynamikę relacji nadawczo-odbiorczych przede wszystkim w perspektywie epistemologicznej. Czytelnik ma świadomość, że „obserwuje” wydarzenie cudzymi oczami, a więc nie ze swojego punktu widzenia. Nie oczekuje więc obiektywizmu. Ponadto zyskuje poczucie kontaktu z konkretną osobą i może mieć wrażenie, że słucha czyjejś opowieści (jak w telewizji i radiu, gdzie komentatorzy są najczęściej znani i występują w swoim imieniu).

36 Piłka nożna, mecz Borussia Dortmund-Real Madryt, autor: Kielbol, 24.10.2012, http://www.realmadryt.pl/index.php?co=mecze\&id=1109\&minuta=ok\&akcja=\&id_pilkarz= [dostęp: 24.03 .2017$]$.

37 Kolarstwo, Tour de Pologne 2013, autor: T. Surma, 31.07.2013, http://archive.lajfy.com/match/index/date/2013-07-31/id/69003 [dostęp: 23.03.2017].

38 Piłka nożna, mecz Liverpool FC-Arsenal Londyn, autor nieznany, 4.03.2017, http://live.Ifc.pl/ [dostęp: 6.03.2017].

39 Podobnie zresztą jest $w$ transmisjach telewizyjnych i relacjach radiowych.

40 Warto pamiętać, że wybór konkretnej formy osobowej może wynikać z upodobań lub przyzwyczajeń autora. 
Podobne odczucia przynosi odbiorcom posługiwanie się przez nadawcę drugą osobą liczby mnogiej. Bezpośrednie zwroty do publiczności nadają relacji znamiona bezpośredniego kontaktu:

1 runda

AAAAAAAAAAAAAAAAAAAAAAAAAAAAAA!!!!!!!! NIE UWIERZYCIEEEEEE!! KOOONIEC!!! 10 SEKUND?!!!! FENOMENALNY CHALIDOW! MISTRZEM!!!! WOWOWOWOWOOW! ${ }^{41}$

Ruch żegna się z pucharami, ale po naprawdę dobrej grze, przynajmniej w obronie. Dziękujemy bardzo za udział w relacji i zapraszamy na relację z meczu Legii, która o 21:0o rozpocznie rewanż z Kazachami z Aktobe. Bądźcie z nami! ${ }^{42}$

Apostroficzność takich fragmentów relacji powoduje skrócenie dystansu między nadawcą a czytelnikami. Efekt ten ulega amplifikacji dzięki rezygnacji z form grzecznościowych („Państwo”, „proszę Państwa”). Jest to zjawisko charakterystyczne dla komunikacji internetowej. W sieci sytuacja komunikacyjna sprzyja kontaktom nieformalnym. W transmisjach telewizyjnych bądź radiowych rzadziej stosuje się drugą osobę liczby mnogiej na rzecz bardziej grzecznościowej trzeciej osoby.

\section{Elementy spełniające funkcję fatyczną}

Umiejętność nawiązania, podtrzymania i zakończenia kontaktu z odbiorcami jest jednym z najważniejszych czynników wpływających na relacje nadawczo-odbiorcze w wypowiedziach dziennikarskich. Składnikom inicjalnym i finalnym poświęcona będzie odrębna część opracowania.

$\mathrm{W}$ tradycyjnych mediach elektronicznych nadawca-komentator ma do dyspozycji różnorodne środki wokaliczne, za pomocą których może podtrzymywać zainteresowanie odbiorcy. W przypadku telewizji dopuszczalne są także pauzy, kiedy widzowie śledzą jedynie ikoniczną warstwę transmisji. W relacji internetowej niezbędne jest ciągłe opisywanie zdarzeń. Ze względu na brak wizji i fonii odbiorca jest całkowicie zdany na nadawcę. Stąd m.in. wynika konieczność ciągłego

41 MMA, walka Michał Materla-Mamed Chalidow, autor: B. Szypowski, 28.11.2015, http://www.zczuba.pl/zczuba/14,123357,19262697,ksw-33-czyli-materla-kontra-chalidow-z-czuba-i-na-zywo.html?bo=1 [dostęp: 22.03.2017].

42 Piłka nożna, mecz Metalist Charków-Ruch Chorzów, autorzy: P. Mikołaczyk, M. Kuprowski, 28.08.2014, http://www.zczuba.pl/zczuba/14,123357,16547153,Metalist_Charkow__Ruch_Chorzow_czyli_walka_o_Lige.html?bo=1 [dostęp: 6.03.2017]. 
orientowania czytelników w aktualnych etapach zawodów. Funkcję fatyczną spełniają więc wszelkie komunikaty informujące o rozpoczęciu i zakończeniu danej części wydarzenia:

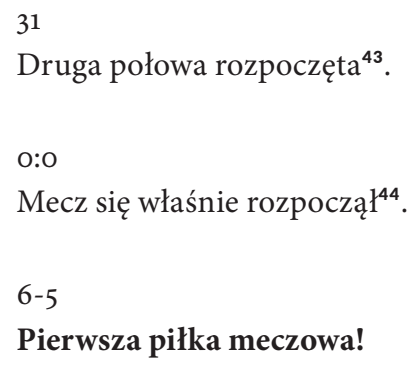

Takie informacje pozwalają także czytelnikowi skupić uwagę na najważniejszych fragmentach zawodów. Dzięki temu wie on, kiedy mogą nastąpić przełomowe momenty, co mobilizuje jego czujność i utrzymuje go przed ekranem komputera (w przypadku powiadomień o zakończeniu danej części zawodów jest odwrotnie - stanowią one sygnał, że można na pewien czas zająć się czymś innym).

Pomocą $\mathrm{w}$ orientacji w przebiegu relacji może być również oznaczanie jej kluczowych elementów, np.:

65 Opis bramki: Wybicie piłki głową przez obrońcę gości, ale bardzo słabe i futbolówka spada pod nogi Portugalczyka, który z 12. metrów „lutnął z dropsa” i Alvarez bez szans ${ }^{46}$.

43 Piłka ręczna, mecz Metz Handball-MKS Selgros Lublin, autor: M. Grzemski, 9.11.2014, http:// archive.lajfy.com/match/index/date/2014-11-09/id/123187 [dostęp: 23.03.2017].

44 Tenis, mecz Gael Monfils-Dominic Thiem, autor: J. Kowalski, 15.11.2016, http://archive.lajfy. com/match/index/date/2016-11-15/id/196576 [dostęp: 10.03.2017].

45 Tenis, mecz Marcin Matkowski/Leander Paes-Aliaksandr Bury/Denis Istomin, autor: J. Kowalski, 25.05.2016, http://archive.lajfy.com/match/index/date/2016-05-25/id/176007 [dostęp: 10.03.2017].

46 Piłka nożna, mecz Real Madryt-Celta Vigo, autorzy: Kiełbol/Theo, 6.12.2014, http://www.realmadryt.pl/index.php?co=mecze\&id=1406\&minuta=ok\&akcja=\&id_pilkarz= [dostęp: 10.03.2017]. 
Podtrzymaniu kontaktu i poprawieniu jego jakości służą wszelkiego rodzaju wyjaśnienia:

Wciąż nie odzyskaliśmy wizji i zmuszeni jesteśmy do podawania skrótowych informacji, bardzo przepraszamy! ${ }^{47}$

20:32 Mamy dłuższą przerwę po pierwszym secie, bo zawiodła technika na hali - elektryczny protokół nie działa ${ }^{48}$,

oraz wszelkie sformułowania o charakterze metatekstowym:

$45^{\prime}+2$ Koniec pierwszej połowy, doliczone były dwie minuty, a nie trzy - przepraszam za pomyłkę. Bez bramek do przerwy, ale końcówka pierwszej połowy zapowiada świetną drugą odsłonę.

Za spełniające przede wszystkim funkcję fatyczną należy uznać te elementy relacji, które nie są bezpośrednimi opisami przebiegu spotkania, a ich główne zadanie to podtrzymanie kontaktu z odbiorcami, kiedy akurat nie dzieje się nic istotnego:

20:02 za nami prawie 3 minuty gry, ale jeszcze żadnej z drużyn nie udało się oddać celnego strzału ${ }^{49}$.

64. min.

Relacjonujemy jedyne ze spotkań Ligi Mistrzów, w którym nie padła żadna bramka. I w ogóle nas to nie dziwi. Można nawet powiedzieć, że jesteśmy już zahartowa$\mathrm{ni}^{50}$.

Podczas przerw odbiorcy, którzy zdecydują się pozostać przed komputerem, mogą liczyć na krótkie podsumowania lub prognozy dotyczące dalszego przebiegu rywalizacji:

47 Snooker, mecz Judd Trump-Stuart Bingham, autor: Artur, 20.11.2013, http://archive.lajfy. com/match/index/date/2013-11-20/id/86007 [dostęp: 10.03.2017].

48 Siatkówka, mecz Polska-Turcja, autor: W. Stelmach, 20.09.2013, http://nazywo.interia.pl/relacja/me-polska-turcja,3883 [dostęp: 20.03.2017].

49 Hokej, mecz Polska-Litwa, autor: G. Wojtowicz, 15.04.2012, http://nazywo.interia.pl/relacja/ polska-litwa,3215 [dostęp: 20.03.2017].

50 Piłka nożna, mecz AS Roma-BATE Borysow, autorzy: P. Jachym, M. Kuprowski, 9.12.2015, http://www.zczuba.pl/zczuba/14,123357,19321232,roma-bate-borysow-czyli-liga-mistrzow-z-czuba-i-na-zywo.html?bo=1 [dostęp: 22.03.2017]. 


\section{PRZERWA}

Manchester dobrze zaczął to spotkanie i szybko objął prowadzenie, ale na przerwę to piłkarze Wolfsburga schodzą zadowoleni. Prowadzą 2:1 i jeśli tak zakończy się mecz to zajmą pierwsze miejsce $\mathrm{w}$ grupie, a Manchester pożegna się z rozgrywkami bo PSV remisuje z CSKA Moskwa. Holendrom do awansu przy przegranej United wystarcza remis ${ }^{51}$.

Druga seria zapowiada się bardzo ciekawie! Jej start przewidziany jest na godzinę 19:40, więc wracamy za kilkanaście minut! ${ }^{52}$

Niekiedy zdarza się, że autor relacji dla wypełnienia czasu w przerwie meczu publikuje różnorodne statystyki, infografiki lub wpisy z Twittera (Fot. 1), np.:

W przerwie można spojrzeć na statystyki trenerów ${ }^{53}$.

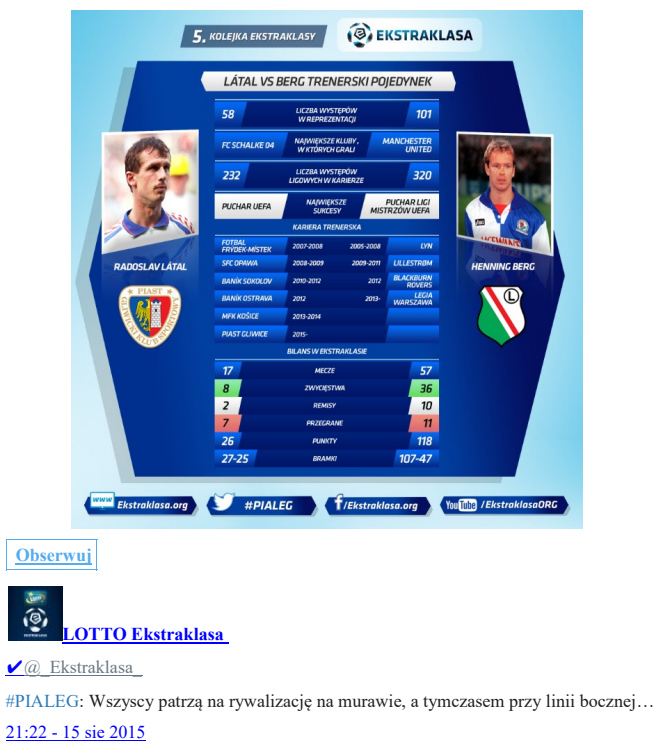

\section{Fot. 1}

\section{Źródło: http://www.legia.net/index.php?typ=relacja\&id=433 [dostęp: 20.03.2017].}

51 Piłka nożna, mecz VFL Wolfsburg-Manchester United, autorzy: P. Jachym, K. Sobczak, 8.12.2015, http://www.zczuba.pl/zczuba/14,123357,19314969,vfl-wolfsburg-manchester-united-czyli-liga-mistrzow-z-czuba.html?bo=1 [dostęp: 24.03.2017].

52 Skoki narciarskie, zawody Letniego Grand Prix w Einsiedeln, autor: P. Szymański, 17.08.2013, http://archive.lajfy.com/match/index/date/2013-08-17/id/73410 [dostęp: 23.03.2017].

53 Piłka nożna, mecz Piast Gliwice-Legia Warszawa, autor nieznany, 15.08.2015, http://www. legia.net/index.php?typ=relacja\&id=433 [dostęp: 20.03 .2017 ]. 
Innym sposobem podtrzymania kontaktu i zwrócenia uwagi odbiorcy są pytania retoryczne, które w relacjach internetowych „na żywo” padają stosunkowo rzadko, warto jednak odnotować, że bywają stosowane:

2015-11-28 10:51

Kowalczyk wpada do trzeciej dziesiątki. Na trasie liczy się już tylko Weng, ale czy jest w stanie rzucić jej wyzwanie? Zapewne nie... ale zobaczymy ${ }^{54}$.

Tym razem rywalem Basketu będzie zajmująca jedną pozycję wyżej drużyna Widzewa Łódź. Oba zespoły nie grają zbyt dobrze w tym sezonie. Tylko kilka dobrych spotkań i więcej porażek niż zwycięstw.

Ba! W przypadku Basketu Gdynia to tylko jedna wygrana i aż 9 porażek. Czy może być gorzej? Wygrały tylko 5 kolejek temu z ostatnią drużyną z Konina 77:54 ${ }^{55}$.

Pojawiające się podczas relacji pytania wytwarzają wrażenie dialogiczności przekazu. Autor niekiedy zdaje się snuć rozważania również w imieniu czytelników, zgadując ich myśli i wątpliwości. Ograniczona jest natomiast funkcja perswazyjna pytań retorycznych. Przewidywania dotyczące wyniku zawodów są raczej formą podtrzymania kontaktu, kiedy wydarzenie jeszcze się nie zaczęło bądź trwa przerwa. Nie chodzi tu więc o przekonanie odbiorców do punktu widzenia nadawcy (lub jest to celem drugorzędnym).

\section{Formuły inicjalne i finalne}

Elementy rozpoczynające i kończące tekst, jak wspomniano, spełniają także funkcję fatyczną - odpowiadają bowiem za nawiązanie i zakończenie kontaktu. W przypadku relacji internetowych „na żywo" określenie momentu początkowego i finalnego nie jest oczywiste (podobnie jak w transmisji telewizyjnej ${ }^{56}$ ). Czy relacją są już pierwsze wpisy znajdujące się pod danym linkiem lub hiperłączem? Zazwyczaj mają one charakter powitalny i wprowadzający. W przypadku niektórych witryn (np. lajfy.com) pojawiają się one na kilka godzin przed rozpoczęciem samych zawodów (lub nawet jeszcze poprzedniego dnia). Podobnie jest na drugim biegunie strukturalnym - czy relacja kończy się wraz z zakończeniem wydarzenia?

54 Biegi narciarskie, zawody PŚ w Kuusamo, autor: M. Kuprowski, 28.11.2015, http://www.zczuba.pl/zczuba/14,123357,19260251,5-km-stylem-dowolnym-w-kuusamo-czyli-justyna-kowalczyk-w-ps.html?bo=1 [dostęp: 22.03.2017].

55 Koszykówka, mecz Basket Gdynia-Cosinus Widzew Łódź, autor: P. Grabowski, 13.12.2014, http://archive.lajfy.com/match/index/date/2014-12-13/id/122106 [dostęp: 24.03.2017].

56 Por. B. Grochala, Telewizyjna transmisja..., s. 94-130. 


\section{Rafał Siekiera}

W wielu przypadkach po końcowym gwizdku pojawiają się jeszcze wpisy w skrócie podsumowujące i oceniające zawody.

W niniejszym opracowaniu przyjęto, że całość tekstu towarzyszącego danemu wydarzeniu sportowemu traktowana będzie jako relacja. Przemawia za tym m.in. fakt, że wpisy ukazujące się jeszcze przed meczem/wyścigiem/walką zawierają powitania i zaproszenia do śledzenia relacji, np.:

Witamy! Już za nieco ponad godzinę Legia Warszawa zmierzy się na wyjeździe z Ajaksem Amsterdam w ramach rewanżowego starcia 1/16 finału Ligi Europy! $!^{57}$

W dalszych wpisach natomiast elementy te nie zostają już powtórzone (podczas gdy w transmisji telewizyjnej oddzielnie witają się z widzami prezenterzy w studiu i komentatorzy):

Skład Legii prezentuje się następująco: Malarz - Broź, Dąbrowski, Pazdan, Hlousek - Jodłowiec, Kopczyński - Guilherme, Odjidja-Ofoe, Kazaiszwili - Kucharczyk!

Kapitanem „Wojskowych” w dzisiejszym meczu będzie Michał Kopczyński Wsparcie z trybun od polskiej sędziny piłkarskiej :) [tu zdjęcie z Twittera - przyp. R.S.]

Obie ekipy wychodzą na murawę! Holendrzy przygotowali specjalną oprawę na to spotkanie.

Komplet publiczności na stadionie Amsterdamie. Szykuje się niesamowite widowisko!

Gramy! ${ }^{58}$

Ponadto relacja internetowa ma jednego nadawcę, a nie, jak w przypadku telewizji - wielu (nadawca instytucjonalny, prezenter i eksperci w studiu, komentatorzy, sami zawodnicy, sędziowie, trenerzy, kibice). Nawiązanie i zakończenie kontaktu między jednym autorem a czytelnikami następuje więc w momencie ukazania się pierwszego oraz ostatniego wpisu. Warto także pamiętać, że krótkie wprowadzenia do zawodów i podsumowania budują pozycję nadawcy jako znawcy, który nie ogranicza się jedynie do suchego spisywania następujących po sobie wydarzeń.

57 Piłka nożna, mecz AFC Ajax Amsterdam-Legia Warszawa, autor nieznany, 23.02.2017, http:// www.legia.net/index.php?typ=relacja\&id=546 [dostęp: 6.03 .2017 ].

58 Tamże. 
Biorąc pod uwagę powyższe argumenty, w badaniu posłużono się szerokim rozumieniem relacji „na żywo" 59 (idąc za przykładem Grochali, która wyróżniła telewizyjną transmisję sportową w ujęciu wąskim i szerokim $\left.{ }^{60}\right)$. Wyróżnić można zatem następujące sposoby rozpoczynania relacji:

- krótkie, rzeczowe wprowadzenia, odpowiadające na wszystkie lub część podstawowych pytań dziennikarskich, np.:

Polscy hokeiści walczą w Mińsku Białorusią w swoim drugim meczu turnieju kwalifikacyjnego do igrzysk w Pjongczangu. Interia zaprasza na relację NA ŻYWO! ${ }^{61}$

- formuły inicjalne zawierające dane protokolarne (np. składy zespołów, nazwiska sędziów, listy startowe - w przypadku sportów motorowych):

Witamy w transmisji online. Wydarzenie rozpocznie się o godzinie 14:00.

Zapraszamy na relacje live z zapowiadającego się pasjonująco GP Monako na ulicznym torze Monte Carlo.

Przed rokiem Circuit de Monaco wygrał Mark Webber. Z kolei rekord toru należy do Michaela Schumachera i został ustanowiony w 2004 roku.

Dane techniczne:

Długość: $3.340 \mathrm{~km}$

Ilość okrąż̇en: 78

Długość wyścigu: $260.520 \mathrm{~km}$

Najlepiej w sesjach treningowych spisywał się Nico Rosberg ze stajni Mercedes AMG Petronas, który wygrał wszystkie trzy sesje.

$[\ldots]$

Pozycje na starcie:

1. Nico Rosberg

2. Lewis Hamilton

3. Sebastian Vettel

4. Mark Webber

$[\ldots]$

Około 10 minut do rozpoczęcia wyścigu.

$[\ldots]$

59 Pozostawiając jednak pewne pole do dyskusji na ten temat, gdyż nie jest to kwestia łatwo rozstrzygalna.

60 Por. B. Grochala, dz. cyt., s. 96.

61 Hokej, mecz Polska-Białoruś, autor: M. Ząbkiewicz, 2.09.2016, http://nazywo.interia.pl/relacja/kwalifikacje-do-io-bialorus-polska,4528 [dostęp: 6.03.2017]. 
Rozpoczęło się okrążenie rozgrzewkowe ${ }^{62}$.

- wprowadzenia zarysowujące kontekst wydarzenia (np. dotychczasowe wyniki, atmosfera na trybunach itp.):

Witamy w relacji!

Przed nami konkurs skoków na dużej skoczni. Na skoczni normalnej Stoch był czwarty, Kot piąty, a Kubacki ósmy. Dla wielu brak medalu był porażką, ale podopieczni trenera Stefana Horngachera do takiego rozstrzygnięcia podeszli za [sic!] spokojem i zapowiadali, że się zrewanżują.

Ich najgroźniejszymi rywalami będą ci, którzy w sobotę stanęli na podium: Austriak Stefan Kraft oraz Niemcy - Andreas Wellinger i Markus Eisenbichler. W środę zawodnicy w bardzo trudnych warunkach rywalizowali w kwalifikacjach. - Było bardzo wolno na rozbiegu. Dopóki był deszcz, to nie było tak wielkiego problemu, ale kiedy przekształcił się w śnieg, prędkości wyraźnie spadły. Tuż przed wybiciem, kiedy wjeżdżamy na płaskie, traciliśmy równowagę, a to wybijało z rytmu. Nie chciałbym takich warunków w czwartkowym konkursie - zżymał się Maciej Kot, który skoczył $115 \mathrm{~m}^{63}$.

- formuły inicjalne wyjaśniające techniczne aspekty relacji:

Zapraszamy na relację z Derbów Podkarpacia pomiędzy Siarką Tarnobrzeg a Stalą Mielec na relacjelive.net. Początek spotkania już o godz. 12. Piłkarze Stali Mielec są aktualnym liderem rozgrywek 2 ligi, ale w Tarnobrzegu na pewno nie będzie im łatwo o punkty. Derby zresztą, jak wiadomo, rządzą się własnymi prawami. Oprócz tradycyjnej tekstowej relacji z meczu przebieg spotkania będzie można śledzić na wirtualnym boisku powyżej - będziemy tam prezentować najciekawsze akcje meczowe $\mathrm{w}$ formie animacji graficznych. Podczas spotkania będzie prowadzone [sic!] również szczegółowe statystyki, m.in. posiadanie piłki. Obie drużyny już po rozgrzewce, niedawno zeszły do szatni więc za chwilę możemy spodziewać się ich wyjścia na boisko. Wyjściowe jedenastki wyprowadzane przez trójkę sędziowską właśnie wychodzą na murawę. Początek I połowy ${ }^{64}$.

62 Formuła 1, GP Monako 2013, autor: Piotr, 26.05.2013, http://archive.lajfy.com/match/index/ date/2013-05-26/id/64111 [dostęp: 6.03.2017].

63 Skoki narciarskie, MŚ w Lahti, autor nieznany, 2.03.2017, http://eurosport.onet.pl/zimowe/skoki-narciarskie/skoki-narciarskie-ms-w-lahti-2017-konkurs-indywidualny-na-zywo/4y5106 [dostęp: 6.03.2017].

64 Piłka nożna, mecz Siarka Tarnobrzeg-Stal Mielec, autor nieznany, 17.10.2015, http://relacjelive.net/relacja_na_zywo/siarka_tarnobrzeg-vs-stal_mielec/1076 [dostęp: 3.03.2017]. 
W badanym materiale najczęściej występują formuły prezentujące kontekst wydarzenia. Nadawca, jak wspomniano, stawia się wówczas w roli eksperta, który ma należyte rozeznanie w rozgrywkach. Dzięki temu może zbudować odpowiedni autorytet. Rozważania kontekstualne mają też znaczenie z punktu widzenia podtrzymania kontaktu z czytelnikami - wypełniają czas pozostający do rozpoczęcia zawodów, sygnalizują, że redakcja już żyje wydarzeniem i stanowią namiastkę dyskusji poprzedzającej rywalizację sportową (jak rozmowa dziennikarza z ekspertami w studiu przed transmisją telewizyjną w ujęciu wąskim).

Należy także zaznaczyć, że $\mathrm{w}$ wielu relacjach wprowadzenia mają charakter mieszany - zawierają elementy więcej niż jednej z wymienionych powyżej kategorii. Są także rozbudowywane o inne składowe, m.in. komunikaty o charakterze autopromocji:

2015-10-11 21:00

Ten dzień to dzisiaj, ten mecz to już za 45 minut! Polska zagra z Irlandią w meczu o niezawracanie sobie głowy barażami w procesie kwalifikacji na mistrzostwa Europy we Francji! Żeby awansować, biało-czerwoni muszą wygrać lub zremisować o:o albo 1:1. Wyższe remisy dadzą już drugie miejsce Irlandii. [...]

2015-10-11 21:10

Jeśli z niezrozumiałych przyczyn nie oglądacie meczu, zrozumiałe będzie, jeśli postępy naszych reprezentantów prześledzicie w naszej relacji. A ją z kolei podglądać możecie w darmowej aplikacji Sport.pl Live na smartfony z Androidem i Windows Phone oraz iPhone'y.

Wszystkie wersje aplikacji znajdziecie $\mathbf{t u}^{65}$ [w tym miejscu pojawia się link do strony z aplikacją - przyp. R.S.],

lub wyjaśnienia dotyczące ewentualnych opóźnień w zawodach:

Witamy w transmisji online. Spotkanie rozpocznie się o godzinie 10:0o. Serdecznie zapraszam na BMW Malaysian Open. Magda Linette - Ying-Ying Duan. To mecz 1/4 finału. Magda jak na razie radzi sobie na tym turnieju całkiem dobrze, ale i ma też trochę szczęścia. [...]

$\mathrm{Na}$ relację z tego meczu zapraszam około godziny 10:0o. Bądźcie z nami na portalu LAJFY COM!

Przedłuża się mecz poprzedzający te spotkanie. Na występ Magdy Linette musimy jeszcze poczekać.

65 Piłka nożna, mecz Polska-Irlandia, autorzy: M. Kuprowski, A. Kulasek, 11.10.2015, http://www. zczuba.pl/zczuba/14,123357,19005579,polska-irlandia-czyli-walka-o-euro-2016-z-czuba-i-na-zywo.html?PageNumber=4 [dostęp: 6.03.2017]. 
Mecz poprzedzający dobiegł końca, już niedługo na korcie powinna pojawić się Magda. Już niedługo początek spotkania, serwis Duan.

Mecz się właśnie rozpoczą ${ }^{66}$.

Samo rozpoczęcie zawodów sygnalizowane jest prostym, konkretnym komunikatem:

Sędzia rozpoczął mecz ${ }^{67}$.

Początek meczu w Sandomierzu ${ }^{68}$.

Niekiedy informacja o otwarciu zawodów przybiera postać czasownika w formie pierwszej osoby liczby pojedynczej:

Zaczynamy! ${ }^{69}$,

również w formie nieco bardziej rozbudowanej:

1. minuta: Darko Jevtić do Łukasza Trałki i gramy! ${ }^{70}$

Wpisy bezpośrednio odnoszące się do początku meczu/walki/wyścigu stanowią formuły inicjalne relacji w ujęciu wąskim i skupiają uwagę odbiorcy, delimitując ramę wydarzenia. Podobną funkcję spełniają komunikaty informujące o zakończeniu zawodów:

Koniec meczu'

Koniec wyścigu ${ }^{72}$.

66 Tenis ziemny, mecz Magda Linette-Ying-Ying Duan, autor nieznany, 3.03.2017, http://www. lajfy.com/match/index/date/2017-03-03/id/202068 [dostęp: 6.03.2017].

67 Piłka nożna, mecz Club America-Real Madryt, autor: P. Pieprzyca, 15.12.2016, http://nazywo. interia.pl/relacja/kms-club-america-real-madryt,4577 [dostęp: 6.03.2017].

68 Piłka nożna, mecz Wisła Sandomierz-Radomiak Radom, autor nieznany, 17.06.2015, http://relacjelive.net/relacja_na_zywo/wisla_sandomierz-vs-radomiak_radom/1005 [dostęp: 4.03.2017].

69 Piłka nożna, mecz Legia Warszawa-Zoria Ługańsk, autor nieznany, 27.08.2015, http://www.legia. net/index.php?typ=relacja\&id=436 [dostęp: 6.03.2017].

70 Piłka nożna, mecz Podbeskidzie Bielsko-Biała-Lech Poznań, autor nieznany, 9.08.2016, http://www. lechpoznan.pl/first-team,6,relacja-live-podbeskidzie-lech-03,24095.html [dostęp: 6.03.2017].

71 Piłka nożna, mecz Chełmianka Chełm-Olimpia Zambrów, autor nieznany, 16.07.2016, http://relacjelive.net/relacja_na_zywo/chelmianka_chelm-vs-olimpia_zambrow/1128 [dostęp: 6.03.2017].

72 Formuła 1, GP Wielkiej Brytanii 2013, autor: D. Zywica, 30.06.2013, http://archive.lajfy.com/ match/index/date/2013-06-30/id/64288 [dostęp: 6.03.2017]. 
Końcowymi częściami relacji są jednak zazwyczaj nieco szersze wypowiedzi, podsumowujące lub oceniające przebieg wydarzenia oraz zawierające formuły pożegnalne, np.:

To nie był łatwy mecz. Agnieszka Radwańska broniła kilku setboli w pierwszym secie, a w drugim na starcie straciła serwis. Na szczęście udało się szybko to odrobić, co kompletnie zdekoncentrowało rywalkę i przybiło ją psychicznie. Widać było po Brytyjce, iż po re-breaku jest zrezygnowana i pogodzona z porażką. Naomi Broady odpuszczała niektóre piłki, beznadziejnie psuła uderzenia. Krakowianka wybiła jej na ten moment tenis z głowy. Dziękuję za śledzenie relacji i zapraszam do kolejnych na portalu Lajfy.com ${ }^{73}$.

\section{KONIEC}

No i niby narzekaliśmy, niby trochę nudy i przestoje, aż tu nagle: Historia! Na naszych oczach! Real w dziesiątkę wygrywa z Barceloną na wyjeździe! Mimo, że to ona miała te wszystkie optyczne przewagi, przewagi posiadania, okazje itp. Ba, Real strzelił nawet trzy gole, ale bramki Bale’a nie uznał sędzia. I tak barcelońska seria 39 spotkań bez porażki zakończyła się ze smętem. Zdarza się.

Dziękujemy za udział w relacji i zapraszamy na kolejne ${ }^{74}$.

Niemal równie często formuły finalizujące tekst składają się z pojedynczych zdań lub samego poinformowania o końcowym wyniku (uzupełnionych ewentualnie operatorami pożegnania):

Na boisku pojawił się jeszcze Alexander-Arnold, ale to już nie jest istotne - koniec meczu! Trzy punkty zostają na Anfield. Dziękuję Państwu za uwagę, do zobaczenia na kolejnych relacjach! ${ }^{75}$

9o+5' Koniec meczu. Ruch zremisował w Niecieczy o:o i zdobył kolejny cenny punkt. Dziękujemy za uwagę ${ }^{76}$.

73 Tenis ziemny, mecz Agnieszka Radwańska-Naomi Broady, autor: Krzysztof, 1.09.2016, http:// archive.lajfy.com/match/index/date/2016-09-01/id/190608 [dostęp: 6.03.2017].

74 Piłka nożna, mecz FC Barcelona-Real Madryt, autor: M. Kuprowski, 2.04.2016, http://www. zczuba.pl/zczuba/14,123357,19857553,el-clasico-fc-barcelona-real-madryt-w-la-liga-z-czuba-i-na.html?bo=1 [dostęp: 4.03.2016].

75 Piłka nożna, mecz Liverpool FC-Arsenal Londyn, 4.03.2017, autor nieznany, http://live.lfc.pl/ [dostęp: 6.03.2017].

76 Piłka nożna, mecz Termalica Nieciecza-Ruch Chorzów, autor: Ryan (WTM), 4.03.2017, http:// www.live.niebiescy.pl/ [dostęp: 6.03.2017]. 
Na uwagę zasługuje fakt, że większość fragmentów finalnych nie tylko spełnia funkcję delimitacyjną, ale także wpływa na budowanie przywiązania odbiorców do danej witryny. Nadawcy, kończąc przekaz, jednocześnie zapraszają na kolejne relacje i zachęcają do ich śledzenia.

\section{Interaktywność}

Charakterystyczna dla relacji internetowych „na żywo” jest interaktywność, wynikająca bezpośrednio z możliwości, jakie daje medium. Wpływa to na sytuację nadawczo-odbiorczą. Co prawda w telewizji i radiu możliwe są interakcje z odbiorcami (m.in. konkursy SMS-owe lub - za pośrednictwem mediów społecznościowych - możliwość odpowiadania przez komentatorów na maile od widzów), jednak Internet przewyższa pod tym względem tradycyjne media. Zwyczajowa sytuacja komunikacyjna ulega wyraźnej zmianie - odbiorcy stają się aktywni i w pewnym sensie uczestniczą w powstawaniu komunikatu.

W przypadku relacji sportowych najczęstszą formą interakcji jest publikowanie przez autorów wpisów komentujących wydarzenia w mediach społecznościowych (dominuje Twitter). W ten sposób każdy odbiorca ma możliwość wyrazić swoją opinię, ewentualnie podzielić się spostrzeżeniami lub emocjami. Często cytowane są posty kibiców znajdujących się na trybunach, dzięki czemu zakres interakcji ulega poszerzeniu. Sama relacja zaś staje się komunikatem wielogłosowym.

Niektóre witryny umożliwiają także odbiorcom dodawanie na bieżąco komentarzy. Osoby obserwujące rywalizację sportowców w telewizji (lub za pośrednictwem internetu) mają możliwość dzielenia się własnymi przemyśleniami. Ich dyskusje tworzą niejednokrotnie całe wątki, będące w zasadzie niemal odrębnymi relacjami - czytelnik, niemający dostępu do transmisji wideo, czerpie z komentarzy innych internautów wiedzę, której nie zapewnia mu autor relacji. Obraz wydarzenia, który w ten sposób uzyskuje, jest wielowarstwowy i składa się z różnych punktów widzenia.

Pewną formą odpowiedzi odbiorców na wpisy składające się na relację „na żywo” są przyciski „polub”, „lubię to”, „nie lubię tego” itp. Nie ma jednak całkowitej jasności, do czego się one odnoszą. Czy kliknięcie przycisku „fajne to” bądź „smutne to" na portalu zczuba.pl jest sposobem na wyrażenie swojej opinii o danym fragmencie relacji? Może odnosi się do sytuacji, która jest prezentowana przez autora relacji? Najbardziej prawdopodobna wydaje się druga możliwość. W obu przypadkach jednak nadawca może odnieść korzyść z takiej formy sprzężenia zwrotnego. W pierwszym bowiem dowiadywałby się, co czytelnicy sądzą o jego sposobie relacjonowania zawodów, w drugim - jak reagują na wydarzenia na arenie sportowej i jakie są ich nastroje.

Ostatnim sposobem uaktywnienia odbiorców relacji są interaktywne quizy. Przypominają one konkursy ogłaszane przez komentatorów podczas transmisji 
telewizyjnych. Możliwość sprawdzenia swojej wiedzy (rzadziej zdobycia nagrody) stanowi dodatkową atrakcję, wypełnia czas, jeśli akurat trwa przerwa w zawodach, oraz zachęca do śledzenia innych relacji na tym samym portalu. Przyczynia się więc do powstania lub wzmocnienia więzi między czytelnikiem a witryną.

\section{Podsumowanie}

Internetowa relacja sportowa "na żywo" pod wieloma względami przypomina transmisje telewizyjne i radiowe. Nieco inaczej jednak rysuje się w jej przypadku sytuacja nadawczo-odbiorcza. Dystans między autorem a czytelnikami jest znacznie mniejszy niż w tradycyjnych mediach. Przejawia się to m.in. w dużej frekwencji form pierwszej osoby liczby mnogiej w funkcji „MY” inkluzywnego oraz bezpośrednich zwrotach do odbiorców. Są one najczęściej sformułowane w drugiej osobie liczby mnogiej, co sugeruje większą poufałość.

Dbałość o kontakt $\mathrm{z}$ odbiorcami i chęć zbliżenia do nich można zaobserwować także w innych elementach relacji. Elementy inicjalne i finalne zarysowują wyraźnie dążenie do zbudowania więzi - funkcję taką spełniają zwłaszcza liczne podziękowania za wspólnie spędzony czas oraz zachęty do śledzenia kolejnych relacji. Kontakt nawiązany przez autora w pierwszych wpisach podtrzymywany jest za pomocą różnorodnych środków, m.in. zwracania uwagi czytelnika na najważniejsze momenty zawodów, podsumowywania części już zamkniętych i prognozowania przebiegu następnych etapów, wypełniania czasu w przerwach ocenami, analizami, danymi statystycznymi, cytatami z mediów społecznościowych. Udogodnieniem dla odbiorców są z pewnością linki do aplikacji, za pomocą których można obserwować relacje w urządzeniach mobilnych.

Cechą odróżniającą relacje internetowe od transmisji telewizyjnych i radiowych jest większa interaktywność. Przejawia się ona w możliwości komentowania zawodów przez czytelników, cytowaniu wpisów kibiców z mediów społecznościowych, konkursach, quizach, przyciskach pozwalających ocenić dany fragment wydarzenia lub samej relacji. Staje się ona zatem wypowiedzią wielogłosową, w której momentami zaciera się granica między nadawcą medialnym a odbiorcami (sami mogą stać się nadawcami).

Wydaje się także, iż możliwość współuczestniczenia w wydarzeniu sportowym z autorem relacji, który obserwuje zawody, z innymi czytelnikami oraz z kibicami obecnymi na trybunach sprawia, że warstwa opisowa, ideacyjna relacji traci na znaczeniu. Istotniejsze staje się wspólne przeżywanie widowiska, a nadawca główny (jeśli można tak nazwać relacjonującego zawody) nie jest pośrednikiem między światem przedstawionym a odbiorcami, lecz zaledwie jednym $\mathrm{z}$ wielu obserwatorów. 


\section{Bibliografia}

Grochala B., Telewizyjna transmisja sportowa w ujęciu genologii lingwistycznej. Na materiale transmisji meczów piłki nożnej, Wydawnictwo UŁ, Łódź 2016.

Grochala B., Ten sam gatunek $w$ dwóch odmianach - o telewizyjnej i internetowej relacji sportowej na żywo, [w:] Gatunki mowy i ich ewolucja, t. 4: Gatunek a komunikacja społeczna, red. D. Ostaszewska, Wydawnictwo UŚ, Katowice 2011, s. 169-180.

Kłosińska K., Retoryka form osobowych $w$ dyskursie politycznym, „Poradnik Językowy" 2004, z. 1, s. 19-38.

Kuszewski S., Widowisko telewizyjne, Wydawnictwa Artystyczne i Filmowe, Warszawa 1971.

Lalewicz J., Retoryka kategorii osobowych, [w:] Tekst i zdanie. Zbiór studiów, red. T. Dobrzyńska, E. Janusz, Zakład Narodowy im. Ossolińskich, Wrocław 1983, s. 267-280.

Lisowska-Magdziarz M., Analiza tekstu $w$ dyskursie medialnym, Wydawnictwo UJ, Kraków 2006.

Loewe I., Sport $w$ mediasferze z perspektywy lingwisty, „Postscriptum Polonistyczne” 2014, nr 2, s. 71-91.

Ostrowski A., Dziennikarstwo sportowe, Dolnośląska Szkoła Wyższa Edukacji Towarzystwa Wiedzy Powszechnej, Wrocław 2003.

Ostrowski A., Telewizyjna transmisja sportowa czyli największy teatr świata, Wydawnictwo Naukowe Dolnośląskiej Szkoły Wyższej Edukacji TWP, Wrocław 2007.

Pol M., Dziennikarstwo sportowe 2.0, rozm. przepr. P. Szews, [w:] P. Szews, R. Siekiera, Zawód: dziennikarz/komentator sportowy. Kulisy pracy i warsztatu, Wydawnictwo UŁ, Łódź 2016, s. 179-192.

Smokowski T., Posiedzę z wami dziewięćdziesiąt minut, a potem mnie wyłaczycie, [w:] Biblia dziennikarstwa, red. A. Skworz, A. Niziołek, Wydawnictwo Znak, Kraków 2010, s. 179-191.

Stec R., Krytyczne spojrzenie na futbolowy mikrokosmos, rozm. przepr. P. Szews, [w:] P. Szews, R. Siekiera, Zawód: dziennikarz/komentator sportowy. Kulisy pracy i warsztatu, Wydawnictwo UŁ, Łódź 2016, s. 127-142.

Szews P., Internetowa relacja „live”, [w:] P. Szews, R. Siekiera, Zawód: dziennikarz/ komentator sportowy. Kulisy pracy $i$ warsztatu, Wydawnictwo UŁ, Łódź 2016, s. 69-84.

Szews P., Siekiera R., Zawód: dziennikarz/komentator sportowy. Kulisy pracy i warsztatu, Wydawnictwo UŁ, Łódź 2016.

Wilkoń A., Funkcje kategorii gramatycznych $w$ tekstach literackich, cz. 1: Kategoria osoby, red. A. Wilkoń, „Język Artystyczny” 1986, t. 4, s. 9-31. 


\section{Źródła}

Biegi narciarskie, zawody PŚ w Kuusamo, autor: M. Kuprowski, 28.11.2015, http:// www.zczuba.pl/zczuba/14,123357,19260251,5-km-stylem-dowolnym-w-kuusamo-czyli-justyna-kowalczyk-w-ps.html?bo=1 [dostęp: 22.03.2017].

Formuła 1, GP Monako 2013, autor: Piotr, 26.05.2013, http://archive.lajfy.com/match/index/date/2013-05-26/id/64111 [dostęp: 6.03.2017].

Formuła 1, GP Wielkiej Brytanii 2013, autor: D. Zywica, 30.06.2013, http://archive. lajfy.com/match/index/date/2013-06-30/id/64288 [dostęp: 6.03.2017].

Formuła 1, Grand Prix Japonii 2013, 13.10.2013, autor: R. Gnutek, http://archive.lajfy. com/match/index/date/2013-10-13/id/77982 [dostęp: 9.03.2017].

Futsal, mecz FC Toruń-Clearex Chorzów, autor: D. Czempisz, 21.11.2015, http://archive.lajfy.com/match/index/date/2015-11-21/id/164785 [dostęp: 8.03.2017].

Futsal, mecz KF Tirana-Gatta Active Zduńska Wola, autor: B. Dąbrowski, 18.08.2016, http://archive.lajfy.com/match/index/date/2016-08-18/id/181457 [dostęp: 8.03.2017].

Hokej, mecz Polska-Białoruś, autor: M. Ząbkiewicz, 2.09.2016, http://nazywo.interia. $\mathrm{pl} /$ relacja/kwalifikacje-do-io-bialorus-polska,4528 [dostęp: 6.03.2017].

Hokej, mecz Polska-Litwa, autor: G. Wojtowicz, 15.04.2012, http://nazywo.interia.pl/ relacja/polska-litwa,3215 [dostęp: 20.03.2017].

Hokej, mecz Polska-Włochy, autor: M. Ząbkiewicz, 19.04.2015, http://nazywo.interia.pl/relacja/ms-w-krakowie-polska-wlochy,4203 [dostęp: 8.03.2017].

Kolarstwo, Tour de Pologne 2013, autor: T. Surma, 31.07.2013, http://archive.lajfy. com/match/index/date/2013-07-31/id/69003 [dostęp: 23.03.2017].

Koszykówka, mecz Basket Gdynia-Cosinus Widzew Łódź, autor: P. Grabowski, 13.12.2014, http://archive.lajfy.com/match/index/date/2014-12-13/id/122106 [dostęp: 24.03.2017].

Koszykówka, mecz CCC Polkowice-ŽKK Novi Zagreb, autor: P. Szarwark, 20.11.2013, http://archive.lajfy.com/match/index/date/2013-11-20/id/86177 [dostęp: 8.03.2017].

Koszykówka, mecz Polska-Ukraina, autor nieznany, 23.08.2013, http://archive.lajfy. com/match/index/date/2013-08-23/id/74098 [dostęp: 8.03.2017].

Lekkoatletyka, Mistrzostwa Świata 2015 - konkurs rzutu dyskiem, autor: K. Sobczak, 29.08.2015, http://www.zczuba.pl/zczuba/14,123357,18651752,wzorzec-relacji-na-zywo-wall-dla-serwisow-nie-kasowac.html?wall $=1 \& b o=1 \quad[$ dostęp: 8.03.2017].

MMA, walka Michał Materla-Mamed Chalidow, autor: B. Szypowski, 28.11.2015, http://www.zczuba.pl/zczuba/14,123357,19262697,ksw-33-czyli-materla-kontra-chalidow-z-czuba-i-na-zywo.html?bo=1 [dostęp: 22.03.2017]. 
Piłka nożna, mecz AFC Ajax Amsterdam-Legia Warszawa, autor nieznany, 23.02.2017, http://www.legia.net/index.php?typ=relacja\&id=546 [dostęp: 6.03.2017].

Piłka nożna, mecz AS Roma-BATE Borysow, autorzy: P. Jachym, M. Kuprowski, 9.12.2015, http://www.zczuba.pl/zczuba/14,123357,19321232,roma-bate-borysow-czyli-liga-mistrzow-z-czuba-i-na-zywo.html?bo=1 [dostęp: 22.03.2017].

Piłka nożna, mecz Borussia Dortmund-Real Madryt, autor: Kielbol, 24.10.2012, http://www.realmadryt.pl/index.php?co=mecze\&id=1109\&minuta $=$ ok\&akcja $=\&$ id_pilkarz= [dostęp: 24.03.2017].

Piłka nożna, mecz Chełmianka Chełm-Olimpia Zambrów, autor nieznany, 16.07.2016, http://relacjelive.net/relacja_na_zywo/chelmianka_chelm-vs-olimpia_zambrow/1128 [dostęp: 6.03.2017].

Piłka nożna, mecz Club America-Real Madryt, autor: P. Pieprzyca, 15.12.2016, http:// nazywo.interia.pl/relacja/kms-club-america-real-madryt,4577 [dostęp: 6.03.2017].

Piłka nożna, mecz Dynamo Kijów-Manchester City, autor: P. Jachym, 24.02.2016, http:// www.zczuba.pl/zczuba/14,123357,19674786,dynamo-kijow-manchester-city-czyli-1-8-finalu-ligi-mistrzow.html?PageNumber=1\&PageStep=1 [dostęp: 5.03.2017].

Piłka nożna, mecz FC Barcelona-Real Madryt, autor: M. Kuprowski, 2.04.2016, http://www.zczuba.pl/zczuba/14,123357,19857553,el-clasico-fc-barcelona-real-madryt-w-la-liga-z-czuba-i-na.html?bo=1 [dostęp: 4.03.2016].

Piłka nożna, mecz KS Rysy Bukowina Tatrzańska-Naprzód Sobolów, autor nieznany, 15.11.2015, http://relacjelive.net/relacja_na_zywo/ks_rysy_bukowina_tatrzanska-vs-naprzod_sobolow/1100 [dostęp: 9.03.2017].

Piłka nożna, mecz Legia Warszawa-Zoria Ługańsk, autor nieznany, 27.08.2015, http:// www.legia.net/index.php?typ=relacja\&id=436 [dostęp: 6.03.2017].

Piłka nożna, mecz Liverpool FC-Arsenal Londyn, autor nieznany, 4.03.2017, http:// live.lfc.pl/ [dostęp: 6.03.2017].

Piłka nożna, mecz Metalist Charków-Ruch Chorzów, autorzy: P. Mikołaczyk, M. Kuprowski, 28.08.2014, http://www.zczuba.pl/zczuba/14,123357,16547153,Metalist_ Charkow__Ruch_Chorzow_czyli_walka_o_Lige.html?bo=1 [dostęp: 6.03.2017].

Piłka nożna, mecz Piast Gliwice-Legia Warszawa, autor nieznany, 15.08.2015, http:// www.legia.net/index.php?typ=relacja\&id=433 [dostęp: 20.03.2017].

Piłka nożna, mecz Podbeskidzie Bielsko-Biała-Lech Poznań, autor nieznany, 9.08.2016, http://www.lechpoznan.pl/first-team,6,relacja-live-podbeskidzie-lech-03,24095. html [dostęp: 6.03.2017].

Piłka nożna, mecz Polska-Irlandia, autorzy: M. Kuprowski, A. Kulasek, 11.10.2015, http://www.zczuba.pl/zczuba/14,123357,19005579,polska-irlandia-czyli-walka-o-euro-2016-z-czuba-i-na-zywo.html?PageNumber=4 [dostęp: 6.03.2017]. 
Piłka nożna, mecz Real Madryt-Celta Vigo, autorzy: Kiełbol/Theo, 6.12.2014, http:// www.realmadryt.pl/index.php? $c 0=$ mecze\&id $=1406 \&$ minuta $=$ ok\&akcja $=\& i d \_p i l-$ karz $=$ [dostęp: 10.03 .2017$]$.

Piłka nożna, mecz Real Madryt-Villarreal CF, autorzy: Kielbol/Theo, 1.03.2015, http://www.realmadryt.pl/index.php?co=mecze\&id $=1447 \&$ minuta $=0$ ok $\& a k c j a=\&$ id_pilkarz= [dostęp: 9.03.2017].

Piłka nożna, mecz Siarka Tarnobrzeg-Stal Mielec, autor nieznany, 17.10.2015, http:// relacjelive.net/relacja_na_zywo/siarka_tarnobrzeg-vs-stal_mielec/1076 [dostęp: 3.03.2017].

Piłka nożna, mecz Stal Stalowa Wola-Olimpia Zambrów, autor nieznany, 24.03.2016, http://relacjelive.net/relacja_na_zywo/stal_stalowa_wola-vs-olimpia_zambrow/1112 [dostęp: 3.03.2017].

Piłka nożna, mecz Termalica Nieciecza-Ruch Chorzów, autor: Ryan (WTM), 4.03.2017, http://www.live.niebiescy.pl/ [dostęp: 6.03.2017].

Piłka nożna, mecz VFL Wolfsburg-Manchester United, autorzy: P. Jachym, K. Sobczak, 8.12.2015, http://www.zczuba.pl/zczuba/14,123357,19314969,vfl-wolfsburg-manchester-united-czyli-liga-mistrzow-z-czuba.html?bo=1 [dostęp: 24.03.2017].

Piłka nożna, mecz Wisła Sandomierz-Radomiak Radom, autor nieznany, 17.06.2015, http://relacjelive.net/relacja_na_zywo/wisla_sandomierz-vs-radomiak_radom/1005 [dostęp: 4.03.2017].

Piłka ręczna, mecz AZS AWF Warszawa-MKS Olimpia-Beskid Nowy Sącz, autor: J. Jurkiewicz, 3.02.2016, http://archive.lajfy.com/match/index/date/2016-02-03/ id/168959 [dostęp: 4.03.2017].

Piłka ręczna, mecz Metz Handball-MKS Selgros Lublin, autor: M. Grzemski, 9.11.2014, http://archive.lajfy.com/match/index/date/2014-11-09/id/123187 [dostęp: 23.03.2017].

Siatkówka, mecz Brazylia-Polska, 29.05.2014, autor: R. Kopeć, http://nazywo.interia. pl/relacja/ls-brazylia-polska,4011 [dostęp: 6.03.2017].

Siatkówka, mecz Polska-Bułgaria, autorzy: P. Pieprzyca, M. Białoński, 31.07.2012, http://nazywo.interia.pl/relacja/io-polska-bulgaria,3457 [dostęp: 8.03.2017].

Siatkówka, mecz Polska-Turcja, autor: W. Stelmach, 20.09.2013, http://nazywo.interia.pl/relacja/me-polska-turcja,3883 [dostęp: 20.03.2017].

Siatkówka, mecz Polska-Włochy, autorzy: P. Mikołajczyk, P. Jachym, 16.07.2015, http://www.zczuba.pl/zczuba/14,123357,18378175,polska-wlochy-czyli-final-six-ligi-swiatowej-z-czuba-i-na.html?PageNumber=5 [dostęp: 8.03.2017]. 
Skoki narciarskie, MŚ w Lahti, autor nieznany, 2.03.2017, http://eurosport.onet.pl/ zimowe/skoki-narciarskie/skoki-narciarskie-ms-w-lahti-2017-konkurs-indywidualny-na-zywo/4y5106 [dostęp: 6.03.2017].

Skoki narciarskie, zawody Letniego Grand Prix w Einsiedeln, autor: P. Szymański, 17.08.2013, http://archive.lajfy.com/match/index/date/2013-08-17/id/73410 [dostęp: 23.03.2017].

Skoki narciarskie, zawody PŚ w Klingenthal, autorzy: M. Kuprowski, B. Szypowski, 22.11.2015, http://www.zczuba.pl/zczuba/14,123357,19228012,konkurs-indywidualny-w-klingenthal-czyli-zaczynamy-puchar-swiata.html?bo=1 [dostęp: 22.03.2017].

Snooker, mecz Judd Trump-Stuart Bingham, autor: Artur, 20.11.2013, http://archive. lajfy.com/match/index/date/2013-11-20/id/86007 [dostęp: 10.03.2017].

Tenis, mecz Gaël Monfils-Dominic Thiem, autor: J. Kowalski, 15.11.2016, http://archive. lajfy.com/match/index/date/2016-11-15/id/196576 [dostęp: 10.03.2017].

Tenis, mecz Marcin Matkowski/Leander Paes-Aliaksandr Bury/Denis Istomin, autor: J. Kowalski, 25.05.2016, http://archive.lajfy.com/match/index/date/2016-05-25/ id/176007 [dostęp: 10.03.2017].

Tenis ziemny, mecz Agnieszka Radwańska-Naomi Broady, autor: Krzysztof, 1.09.2016, http://archive.lajfy.com/match/index/date/2016-09-01/id/190608 [dostęp: 6.03.2017].

Tenis ziemny, mecz Magda Linette-Sloane Stephens, autor: P. Grabowski, 5.08.2015, http://archive.lajfy.com/match/index/date/2015-08-05/id/152155 [dostęp: 24.03.2017].

Tenis ziemny, mecz Magda Linette-Ying-Ying Duan, autor nieznany, 3.03.2017, http:// www.lajfy.com/match/index/date/2017-03-03/id/202068 [dostęp: 6.03.2017].

Rafat Siekiera

\title{
Stosunki nadawczo-odbiorcze w internetowej relacji sportowej „na żywo”
}

\author{
Streszczenie
}

Internetowa relacja sportowa "na żywo" pod wieloma względami przypomina transmisje telewizyjne i radiowe. Nieco inaczej jednak rysuje się w jej przypadku sytuacja nadawczo-odbiorcza. Jak zauważył Jan Chovanec, warstwa ideacyjna relacji sportowej stopniowo usuwana jest na dalszy plan, dominantą funkcjonalną staje się zaś interakcja między nadawcą a odbiorcami. Celem niniejszego badania było scharakteryzowanie sytuacji nadawczo-odbiorczej w internetowych relacjach sportowych „na żywo”. Jak wykazała analiza materiału badawczego, dy- 
stans między autorem a czytelnikami jest znacznie mniejszy niż w tradycyjnych mediach. Przejawia się to m.in. w dużej frekwencji form pierwszej osoby liczby mnogiej w funkcji „MY” inkluzywnego oraz bezpośrednich zwrotach do odbiorców. Komponenty inicjalne i finalne zarysowują wyraźnie dążenie do zbudowania więzi - funkcję taką spełniają zwłaszcza liczne podziękowania za wspólnie spędzony czas oraz zachęty do śledzenia kolejnych relacji. Cechą odróżniającą relacje internetowe od transmisji telewizyjnych i radiowych jest większa interaktywność. Przejawia się ona w możliwości komentowania zawodów przez czytelników, cytowaniu wpisów kibiców z mediów społecznościowych, konkursach, quizach, przyciskach pozwalających ocenić dany fragment wydarzenia lub samej relacji. Staje się ona zatem wypowiedzią wielogłosową, w której momentami zaciera się granica między nadawcą medialnym a odbiorcami (sami mogą stać się nadawcami).

Słowa kluczowe: relacje nadawczo-odbiorcze, internetowa relacja sportowa "na żywo", dziennikarstwo sportowe.

\section{Sender-reader relations in live online commentary}

Summary

Online live commentary, in many ways, is similar to live TV coverage and radio broadcasts. But, as Jan Chovanec noticed, it also differentiates itself from traditional transmissions. One of the differences is the sender-reader relation. The aim of the article is to characterise this relation. As the analysis reveals, the distance between the aforementioned participants of communication is relatively smaller than in traditional media (TV and radio). This is most noticeable in the use of the first person pluralis, in the form of the inclusive WE and of direct address to the reader. The initial and final components of the text show signs of the desire to establish a kind of bond with recipients and, in the longer perspective, a lasting relationship. Another distinctive attribute of live online commentary is its interactivity. Readers can comment on the competition, cite other fans from social media, take part in contests and quizzes, rate the commentary and events on the sports field. The commentary thus becomes a polyphonous message, in which the distinctions between media sender nad recipients becomes blurred.

Keywords: sender-reader relations, live online commentary, sports journalism. 